\title{
Migracije poljoprivrednika u Crnoj Gori (1948.-2011.)
}

\author{
Rade Šarović
}

Filozofski fakultet Nikšić, Studijski program za sociologiju, Univerzitet Crne Gore, Crna Gora

e-mail: sarovicrade@gmail.com

\begin{abstract}
SAŽETAK Ruralna područja Crne Gore posljednjih decenija karakterizira izrazit diskontinuitet u razvoju. Industrijalizacija je, kao i u ekonomski razvijenijim dijelovima svijeta, izazvala procese deagrarizacije i deruralizacije koji se očituju u smanjivanju udjela poljoprivrednog stanovništva u ukupnom stanovništvu i smanjivanju broja stanovnika koji ostaju da žive u selu. Specifičnost tih promjena u Crnoj Gori ogledala se u tome što su one bile veoma brze, znatno brže nego u zemljama u okruženju i u razvijenijim dijelovima svijeta. Udjel poljoprivrednog u ukupnom stanovništvu se za šest decenija smanjio gotovo 12 puta - od oko 80\% neposredno poslije Drugog svjetskog rata, na ispod 10\%, prema najnovijim procjenama. U kratkom vremenskom periodu (čak neprirodno kratkom za ovu vrstu društvenih procesa) ogroman broj ljudi je promijenio mjesto i stil življenja. Ovaj rad predstavlja kratak rezime crnogorske ruralne drame poslednjih decenija, kojoj se kraj ne nazire.
\end{abstract}

Ključne riječi: selo, demografska kretanja, migracije, deagrarizacija, deruralizacija, Crna Gora, starenje stanovništva.

\section{Uvod}

U sociološkom proučavanju demografskih kretanja u ruralnim prodručjima, polazimo od pretpostavke da postoje dva glavna faktora koja suštinski mijenjaju društvenu strukturu savremenog sela i porodice u njemu: 1. brzo smanjivanje broja seljaka kao statističko-demografske kategorije i njihovo društveno-kulturno preoblikovanje prema urbanim obrascima života, i 2. okretanje od poljoprivrede kao izvora dohotka onih stanovnika koji žive na posjedu što rezultira sve većim međusobnim razdvajanjem savremenog sela (koje se urbanizuje) i moderne poljoprivrede (koja se industrijalizuje). Međutim, migracije stanovništva u nekim okvirima nijesu nikakva specifičnost crnogorskog društva. Sve razvijene zemlje svijeta prošle su kroz periode masovnog odlaska, naročito omladine, iz sela i poljoprivrede u gradove i nepoljoprivredne djelatnosti. Erik Hobsbaum smatra da iščezavanje seljaštva kao klase predstavlja jednu od najdalekosežnijih društvenih promjena od druge polovine XX stoljeća. Ovaj autor upućuje na interesantne primjere Španije i Portugalije u kojima je 1950. godine broj poljoprivrednika činio nešto manje od polovine populacije da bi trideset godina kasnije bio smanjen na 14,5\%, zatim Japana gdje je udjel zemljorad- 
nika sa 52,4\% (1947.) smanjen na 8,5\% (1985.), Latinske Amerike i sl. Sela i polja su dominantna jedino u tri regije planete - subsaharskoj Africi, južnoj i kontinentalnoj i istočnoj Aziji i Kini (Hobsbaum, 2002.:221). Za ostale razvijenije evropske i druge zemlje osnovno je što su one, ili većina njih, migracije selo - grad društveno-sistemski kanalisale razvojnom ekonomskom politikom, i usklađivale ih sa razvojem, kako ukupne privrede tako i poljoprivrede.

\section{Predmet i cilj istraživanja}

U Crnoj Gori je, kao i u razvijenijim dijelovima svijeta, društvena i kompletna ruralna struktura duboko uslovljena geografskim položajem, stepenom ekonomskog razvitka, karakterom društvenih odnosa i posebnim istorijskim uslovima. U razdoblju od 1931. do 2011. godine, Crna Gora je tri puta izlazila i ulazila u ratne sukobe, pet puta mijenjala svoj državni status i njeno stanovništvo je doživjelo gotovo jedinstvenu masovnu prostornu i socijalnu pokretlijivost.

Predmet ovoga rada su migracije poljoprivrednog stanovištva Crne Gore od 1948. do 2011. godine.

Cilj istraživanja je ukazati na ulogu i posljedice djelovanja društveno-sistemskih faktora u istorijskom preobražaju crnogorskog društva, od izrazito agrarnog do urbanog kakvo je ono danas.

\section{Migracije stanovništva i regionalne nejednakosti (opšti podaci)}

U razdoblju od 1948. do 2011. iskazale su se velike disproporcije u prostornom razmještaju stanovništva Crne Gore. Sjeverni region zemlje (32,3\% teritorije Crne Gore) je zabilježio apsolutni pad za 10.147 osoba (13,13\%); sjeveroistočni region $(20,6 \%$ teritorije) bilježi pad za 14.167 (9,76\%). Sa druge strane središnji region $(35,6 \%$ teritorije) bilježi porast za 20.398 lica (7,79\%) i, na kraju, primorski region (11,5\% teritorije) povećanje za 13.239 lica (9,82\%) (Bakić, Mijanović, 2006.:13-15; Monstat, 98/2011.:14 i 17).

Tabela 1.

Kretanje stanovništva Crne Gore od 1948. do 2011. godine

\begin{tabular}{|c|c|c|c|c|c|c|c|}
\hline & \multicolumn{7}{|c|}{ Godine popisa } \\
\hline Teritorija & 1948. & 1961. & 1971. & 1981. & 1991. & 2003. & 2011. \\
\hline $\begin{array}{c}\text { Sjeverni } \\
\text { region }\end{array}$ & $\begin{array}{c}77.305 \\
(20,49 \%)\end{array}$ & $\begin{array}{c}93.652 \\
(19,84 \%)\end{array}$ & $\begin{array}{c}92.536 \\
(17,47 \%)\end{array}$ & $\begin{array}{c}83.775 \\
(14,33 \%)\end{array}$ & $\begin{array}{c}75.394 \\
(12,25 \%)\end{array}$ & $\begin{array}{c}67.244 \\
(10,84 \%)\end{array}$ & $\begin{array}{c}67.158 \\
(10,74 \%)\end{array}$ \\
\hline $\begin{array}{c}\text { Sjeveroistočni } \\
\text { region }\end{array}$ & $\begin{array}{c}101.319 \\
(26,86 \%)\end{array}$ & $\begin{array}{l}124.336 \\
(26.34 \%)\end{array}$ & $\begin{array}{l}137.509 \\
(25.96 \%)\end{array}$ & $\begin{array}{c}145.193 \\
(24,84 \%)\end{array}$ & $\begin{array}{c}143.198 \\
(23,28 \%)\end{array}$ & $\begin{array}{r}127.635 \\
(20.58 \%)\end{array}$ & $\begin{array}{c}128.031 \\
(20,47 \%)\end{array}$ \\
\hline $\begin{array}{c}\text { Centralni } \\
\text { region }\end{array}$ & $\begin{array}{l}128.759 \\
(34,13 \%)\end{array}$ & $\begin{array}{c}170.449 \\
(36,12 \%)\end{array}$ & $\begin{array}{c}202.708 \\
(38,27 \%)\end{array}$ & $\begin{array}{c}239.571 \\
(41 \%)\end{array}$ & $\begin{array}{c}261.756 \\
(42,55 \%)\end{array}$ & $\begin{array}{l}279.419 \\
(45,1 \%)\end{array}$ & $\begin{array}{c}282.154 \\
(45,12 \%)\end{array}$ \\
\hline $\begin{array}{c}\text { Primorski } \\
\text { region }\end{array}$ & $\begin{array}{c}69.806 \\
(18.50 \%)\end{array}$ & $\begin{array}{c}83.499 \\
(17.69 \%)\end{array}$ & $\begin{array}{c}96.851 \\
(18,28 \%)\end{array}$ & $\begin{array}{c}115.771 \\
(19.81 \%)\end{array}$ & $\begin{array}{c}134.687 \\
(21,89 \%)\end{array}$ & $\begin{array}{c}145.847 \\
(23,51 \%)\end{array}$ & $\begin{array}{l}147.923 \\
(23.65 \%)\end{array}$ \\
\hline Crna Gora & 377.189 & 471.894 & 529.604 & 584.310 & 615.035 & 620.145 & 625.266 \\
\hline
\end{tabular}

Izvor: Bakić, Mijanović, 2006.:13-15; Monstat, 98/2011.:14 i 17 
Stope prirodnog priraštaja imale su tendenciju stalnog opadanja tokom druge polovine XX stoljeća i sa 15,5\% u periodu 1966.-1970. opale su na 5,5\% do 2004., da bi 2011. godine varirale oko 2\%. Identični procesi bili su u crnogorskim regionima i opštinama (tabela 2.). Ubjedljivo najnepovoljniji odnos mortaliteta i nataliteta imaju opštine sjevernog planinskog regiona Crne Gore (prema najnovijim podacima prosječnu stopu prirodnog priraštaja od -7,4). Znatno povoljnija situacija je u sjeveroistočnom i centralnom dijelu zemlje, a daleko najpovoljnija u primorskom regionu (Bakić, Mijanović, 2006.:20; Monstat, 102/2012.:5-20).

Tabela 2.

Stope prirodnog priraštaja regiona i opština Crne Gore od 1966. do 2011.

\begin{tabular}{|c|c|c|c|c|}
\hline & 1966.-1970. & 1976.-1980. & 2000.-2004. & 2011. \\
\hline Sjeverni region & 13.4 & 8,1 & $-1,2$ & $-7,4$ \\
\hline Savnik & 10,7 & 3,3 & $-5,3$ & $-8,7$ \\
\hline Mojkovac & 21,6 & 14,5 & 4,0 & $-3,1$ \\
\hline Zabljak & 11,5 & 7,5 & $-2,7$ & $-8,4$ \\
\hline Plužine & 12,2 & 6,5 & $-2,3$ & $-10,8$ \\
\hline Kolašin & 11,8 & 8,7 & $-1,6$ & $-6,0$ \\
\hline Pljevlja & 13,0 & 8,3 & 0,7 & $-7,6$ \\
\hline $\begin{array}{c}\text { Sjeveroistočni } \\
\text { region }\end{array}$ & 25,2 & 17,8 & 6,5 & 1,5 \\
\hline Andrijevica & - & - & $-0,9$ & $-5,5$ \\
\hline Bijelo Polje & 22,9 & 17,6 & 5,9 & 2,0 \\
\hline Rožaje & 32,8 & 26,2 & 14,4 & 9,6 \\
\hline Berane & 21,1 & 13,8 & 7,6 & 0,9 \\
\hline Plav & 23,1 & 13,6 & 5,7 & 0,6 \\
\hline $\begin{array}{c}\text { Centralni } \\
\text { region }\end{array}$ & 11,5 & 9,6 & 2,5 & 1,0 \\
\hline Podgorica & 15,9 & 15,4 & 8,4 & 6,2 \\
\hline Nikšić & 15,7 & 11,6 & 4,2 & 0,7 \\
\hline Danilovgrad & 4,6 & 4,8 & $-0,6$ & $-1,2$ \\
\hline Cetinje & 10,1 & 6,8 & $-1,8$ & $-1,4$ \\
\hline Južni region & 8,2 & 8,7 & 2,5 & 2,0 \\
\hline Bar & 9,5 & 7,8 & 3,8 & 2,8 \\
\hline Budva & 1,6 & 13,1 & 5,8 & 5,8 \\
\hline Ulcinj & 15,6 & 9,3 & 3,3 & 1,5 \\
\hline Kotor & 6,5 & 4,9 & $-0,2$ & 1,2 \\
\hline Tivat & 8,6 & 9,6 & 1,4 & 1,1 \\
\hline Herceg Novi & 7,9 & 8,0 & 1,3 & $-0,3$ \\
\hline Crna Gora & 15,5 & 10,5 & 5,5 & 2,2 \\
\hline
\end{tabular}

Izvor: Bakić, Mijanović, 2006.:19-27; Monstat, 102/2012.:5 i 20

Sa apsolutnim rastom ukupnog broja stanovnika, u Crnoj Gori je došlo i do povećanja gustine naseljenosti, sa 27,3 iz 1948. godine na 45 stanovnika po kilometru kvadratnom danas. Međutim, i ovdje se danas primjećuju drastične regionalne razlike i odstupanja. Prema podacima Zavoda za statistiku Crne Gore (grafikon 1.) 2011. godine na $13.812 \mathrm{~km}^{2}$, kolika je površina Crne Gore, najgušće je naseljen primorski region (92 stanovnika po $\mathrm{km}^{2}$ ), pa središnji (57), sjeveroistočni region je na nivou naseljenosti države $\left(45\right.$ po $\left.\mathrm{km}^{2}\right)$, a najslabije je naseljen sjeverni region (15 lica po $\mathrm{km}^{2}$ ). Od opština, najnaseljenija je primorska opština Tivat sa 296 stanovnika po km², a najmanju naseljenost imaju opštine sjevernog dijela Šavnik i Plužine - samo pet stanovnika na jedanom kvadratnom kilometru. Navedene razlike su posljedica djelovanja niza faktora od kojih 
su najznačajniji: raznovrsne klimatske prilike (od primorskog do planinskog regiona), snažna migraciona kretanja stanovništva, izražene razlike u stopama prirodnog priraštaja, ekonomskoj razvijenosti, turističkoj privlačnosti i sl. (Monstat, 83/2012.:9).

Grafikon 1.

Gustina naseljenosti Crne Gore 1948.-2011. i regiona 2011. godine

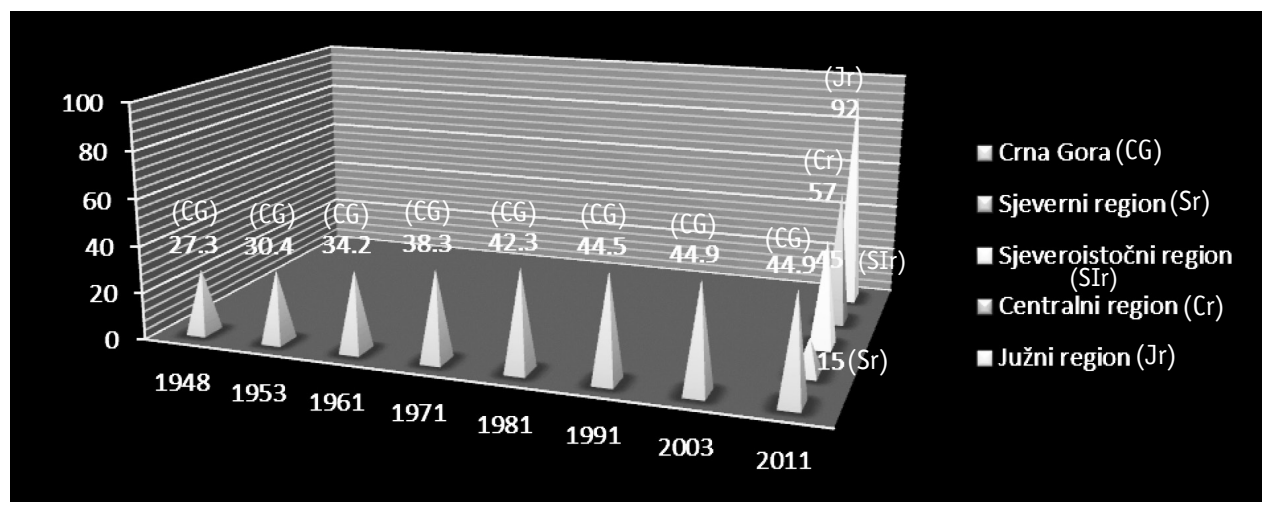

Izvor: Bakić, Mijanović, 2006: 19; Monstat, 83/2012.:9

Ovi statistički podaci pokazuju da kretanje populacije Crne Gore poslednjih decenija karakteriše: nizak porast stanovništva (u odnosu na rast iz ranije popisivanih perioda), izraženo opadanje broja stanovnika u sjevernom i sjeveroistočnom regionu, ekstremna demografska erozija u posljednjim decenijama manjih urbanih centara sjevernog i sjeveroistočnog dijela zemlje, intezivan populacioni rast Podgorice i primorskog regiona.

Crna Gora se u periodu od 1948. do 2011. demografski transformisala od zemlje sa visokim natalitetom, sa harmoničnim razmještajem u prostoru, u zemlju sa niskim stopama nataliteta, niskim i neravnomjernim prirodnim priraštajem, visokim stopama unutrašnjih migracija i sve nepovoljnijim prostornim razmještajem stanovništva. Iz navedenih razloga i migracije stanovništva imaju specifičan tok, dinamiku i posljedice koje jednako pogađaju i one koji ostaju da žive u selu i one koji su svoj život vezali za urbano područje.

Međutim, ako navedene pokazatelje dovedemo u vezu sa društveno-sistemskim faktorima koji su djelovali na ova kretanja, dobićemo odgovor na pitanje zašto je crnogorsko društvo u relativno kratkom vremenu doživjelo jedinstvenu prostornu pokretljivost stanovništva u Evropi i potpunu transformaciju iz čisto agrarnog u djelimično razvijeno urbano društvo, kakvo je danas.

\section{Crna Gora od agrarnog do urbanog društva}

Crnogorsko društvo je početkom XX stoljeća pripadalo izrazito tradicionalnom tipu društva sa autarkičnom naturalnom poljoprivrednom proizvodnjom, nerazvijenom društvenom podjelom rada, okoštalom socijalnom strukturom, djelimičnim kolek- 
tivizmom u sferi svojinskih odnosa i sl. Crna Gora je 1931. godine imala 360.000 stanovnika, (26 stanovnika na jednom kvadratnom kilometru), što znači da je bila najnenaseljeniji dio Kraljevine Jugoslavije. Od ukupnog broja stanovnika više od 80\% je živjelo od poljoprivrede, šumarstva i ribarstva, a u poređenju sa drugim dijelovima tadašnje Jugoslavije, jedino je Bosna i Hercegovina bila ispred (Andrijašević, Rastoder, 2006.:349). Poljoprivreda je bila dominantna privredna grana, ali su njene osnovne karakteristike bile: usitnjenost i rasparčanost zemljišnog posjeda, veoma niski prihodi po jedinici površine, nerazvijenost robne proizvodnje, tradicionalni način obrade zemlje, primitivna sredstva za proizvodnju i sl. (Bulajić, 1959.:269-272).

U Crnoj Gori je između dva svjetska rata došlo do postepenog razvoja industrije - 24 industrijska preduzeća sa ukupno 1.355 radnika (najviše električnih centrala, preduzeća iz oblasti prehrambene industrije, zatim drvne industrije itd.) (Andrijašević, Rastoder, 2006.:349). Primijetna su, dakle, bila određena pomjeranja u društvenoj podjeli rada i razvoju nekih novih industrijskih grana, što je uzrokovalo i razuđeniju društveno-ekonomsku strukturu. Ovo je bio početak procesa koji se lagano kretao od djelimične socio-profesionalne homogenizacije agrarnog tipa društva ka socioprofesionalnoj heterogenizaciji savremenijeg društva. Socio-profesionalna heterogenizacija u tom kontekstu znači proces pojavljivanja novih zanimanja, novih grana djelatnosti, novih socio-profesionalnih kategorija, kao i njihovo razvijanje.

Takva društveno-ekonomska kretanja definitivno su uticala i na promjene u porodičnom poljoprivrednom domaćinstvu, te na blago uvećanje zanatskih, službeničkih i radničkih porodica u gradovima. Međutim, ne može se govoriti o nekoj vidljivoj, a naročito ne o burnoj transformaciji ruralne strukture. Da bi se odnosi na seoskom gazdinstvu mijenjali, potrebna je svakako snažnija i ekonomska i društvena transformacija poretka, koja bi bila prevashodno uzrokovana snažnijom industrijalizacijom i urbanizacijom. Pošto su ovi procesi u Crnoj Gori do 1941. godine izostali, seosko gazdinstvo i porodica u njemu je ostala sačuvana od dubljih i jačih promjena ${ }^{1}$.

Nakon završetka Drugog svjetskog rata i uspostavljanja vlasti od strane komunista, Crna Gora je (odlukama Narodne skupštine iz 1945.) zvanično postala jedna od šest ravnopravnih republika u novoj jugoslovenskoj federaciji. Međutim, u ovoj novoj federaciji prekinuti su, kakvi takvi, procesi stvaranja građanskog društva u ime borbe za "socijalističku izgradnju«, uspostavljena je "narodna vlast» kao monopartijska diktatura. "U takvom sistemu seljaci su dobili 'patriotski zadatak' da 'hrane narod', a naročito 'drugove radnike' koji su izvikani za 'glavnog subjekta socijalističke revolucije'. Ekonomski interes seljaka niko se nije usuđivao da pomene, pa ni oni sami. Na rat se nastavila 'obnova zemlje i izgradnja socijalizma', a jedna od mnogih parola, glasila je: 'nema odmora dok traje obnova', koja se posebno odnosila na seljake» (Mitrović, 1997.:178).

1 Svakako ovdje ne možemo a priori donijeti zaključak da se u njoj nije ništa mijenjalo, ali ta suptilnija i mirnija pomjeranja je nemoguće procjenjivati bez dubinskih i specijalističkih istraživanja za koja u Crnoj Gori nedostaju elementarni statistički podaci. 
Kao i u cijeloj federaciji i u Crnoj Gori donešeni su još 1945. godine zakonski propisi o obaveznom otkupu poljoprivrednih proizvoda, o otkupnim cijenama žitarica, stoke, vune, kože, povrća, mlijeka i mliječnih proizvoda, te mnogih drugih proizvoda za ishranu nepoljoprivrednog stanovništva. Postojanje obaveznog otkupa praktično je isključivalo tržište i svaku legalnu trgovinu poljoprivrednim proizvodima. Umjesto prodaje i kupovine poljoprivredni proizvodi su se "predavali« državi, a vlast ih je potom iz jednog centra dirigovano distribuirala. Za predate proizvode seljaci su dobijali bonove (»tačkice») za koje su mogli da nabave najnužnije nepoljoprivredne proizvode, nesrazmerno manje vrijedne od vrijednosti svojih predatih proizvoda. "Propisi su donošeni svake sledeće godine, što je svakako znak da nisu smatrani jednom stalnom i sistemskom merom agrarne politike« (Mitrović, 1997.:179).

Strateški značaj u ovom modelu društveno-ekonomskog razvoja imalo je opredjeljenje za ubrzanu i prinudnu kolektivizaciju sela i poljoprivrede. Kolektivizacija je započeta 1945. godine formiranjem državnih poljoprivrednih dobara i stvaranjem tzv. seljačkih radnih zadruga (SRZ) koje bi trebalo da omoguće da se zemlja koja je reformom privremeno podijeljena seljacima, kao i druga privatna zemlja, postepeno kolektivizuje. Administriranje prilikom određivanja otkupnih kvota i represija u sprovođenju otkupa djelovali su veoma destimulativno na motivaciju seljaka za rad i proizvodnju hrane. „Obaveze u otkupu su određivane prema planu sjetve, a ne prema stvarno zasijanim površinama i postignutim prinosima. Oduzimalo se koliko se našlo, bez obzira na potrebe samih seljaka, a uzgredno se vršio pritisak za stupanje seljaka u SRZ. Pritisnuti otkupom, mnogi su ulazili u zadruge samo da bi se sklonili od nepodnošljivog pritiska na seljake privatnike« (Horvat, 1976.:785). Razumljivo je što seljaci u takvim uslovima nijesu bili zainteresovani za povećanje proizvodnje. Veća proizvodnja je povlačila i veća davanja prilikom otkupa, a i najveća proizvodnja nije garantovala seljaku da i sam sa svojom porodicom neće ostati bez hrane. »Bilo kako bilo, agrarna politika KPJ kao državne partije od 1948. do 1953. godine značila je blokiranje svih vidova modernizacije na našem selu« (Gudac, 1994.:158).

Sa druge strane, postajala je ogromna potreba stvaranja kadrova i razvoja socijalističkog društveno-političkog i ekonomskog sistema. Selo je predstavljalo "resurs» bogat radnom snagom, koji je doprinosio stvaranju i administrativno rukovodećih slojeva i društveno-političkih organizacija i sindikata (državne uprave od lokalnog do federativnog nivoa), a posebno formiranju velikih industrijskih centara. Na taj način su (usled velikih kapitalnih investicija u većim urbanim centrima), mogućnosti zapošljavanja izvan sela i poljoprivrede postale velike.

Uz inače teške prilike na selu, prinudna kolektivizacija i obaveza pristupanja u SRZ, ubrzale su pravu lavinu onih koji su bježali iz sela i poljoprivrede u gradove i nepoljoprivredna zanimanja (u fabrike i drugdje). Zatvoreni život, posebno crnogorskih planinskih sela, i bez ovih sistemsko-političkih uticaja, bio je više nego težak i skučen za mlade ljude koji u njemu nijesu nalazili svoje mjesto i funkciju. Mogućnosti koje im je nudio grad, bile su raznovrsne. Obrazovanje i zapošljenje su otvarili nove kanale socijalne promocije i mogućnost napredovanja na hijerarhijskoj ljestvici društva. Samo u razdoblju od prvog (1948.) do drugog poslijeratnog popisa (1953.), navedeni faktori i neadekvatne državne politike prema selu, i seljacima, doprinijeli su 
da se udjel poljoprivrednog stanovništva u ukupnom stanovništvu Crne Gore smanji za 14,5\% (Bakić, Mijanović, 2006.:95).

Osamostalivši se i oslobodivši se najuočljivijih obilježja sovjetskog modela, kreatori socijalističke politike prema selu, pedesetih godina prošlog vijeka, nijesu se odrekli administrativnog sprovođenja svoje političke volje u agrarnim odnosima, što je po pravilu bilo neracionalno na ovom ekonomski i geografski specifičnom području. Novi šok za seljake je bila i tzv. mala ili druga agrarna reforma sprovedena Zakonom o poljoprivrednom zemljišnom fondu iz 1953. godine. Tada je izvršena nova eksproprijacija kojom je smanjen zemljišni maksimum (od 25 do 35 ha) i zemlja oduzeta svima onima koji su je imali više od 10 ha (u planinskim krajevima preko 15 ha). Oduzeta zemlja ovog puta nije dijeljena siromašnim seljacima nego je najvećim dijelom dodijeljena državnim (»društvenim«) poljoprivrednim dobrima i agroindustrijskim kombinatima, manjim delom SRZ, a još manjim zemljoradničkim zadrugama opšteg tipa. Smatralo se da 10 ha površine jedno seljačko domaćinstvo može obrađivati bez unajmljene radne snage. Oduzimanje zemlje seljacima i smanjenje posjeda na 10 ha, sa jedne strane, i prednosti života i rada u gradu sa druge, o kojima govori Vlado Puljiz², doprinose da se u tom periodu (od 1953. do 1961.) transfer crnogorskog seoskog stanovništva u urbane sredine nastavlja gotovo istim intezitetom, pa je i pad bio gotovo identičan u odnosu na prošli period i iznosio je 14,4\% (Bakić, Mijanović, 2006.:98).

Privatno seljačko gazdinstvo je u tom periodu imalo izvjesnu garanciju za svojinu nad zemljom, koju je seljak stekao ličnim radom i koju sam obrađuje, ali je u svemu drugom ono bilo upućeno na kooperaciju sa socijalističkim sektorom poljoprivrede. »Oni sa kojima su seljaci 'kooperirali' i sa kojima su se 'udruživali' (agrokombinati i zadruge) imali su sistemsku mogućnost da seljacima sistematski zakidaju na cijeni njihovih proizvoda, na mjeri, na vremenu isplate seljačkih potraživanja, na transportu i drugim proizvodnim i neproizvodnim uslugama na koje su imali monopol i koje seljaci nisu mogli ni birati ni izbjeći« (Veselinov, 1987.:282).

Analizirajući agrarne odnose u jugoslovenskoj federaciji u periodu od 1945. do 1981. godine, Milovan Mitrović ističe da se poljoprivreda mogla razvijati i agrarni odnosi su se mogli mijenjati, ali je obavezno bilo da se to uvijek odvija u "socijalističkim oblicima«. "Ovi 'socijalistički oblici' agrarnih odnosa, ili tzv. socijalističke poljoprivredne organizacije, jedan za drugim su pokazivali svoju ekonomsku neracionalnost. Seljacima su bili nepodesni, kad god su mogli da ih izbegnu to su činili (te su im se morali raznim sredstvima nametati), a na kraju su postali preteško breme i za socijalističku vlast« (Mitrović, 1997.:195).

2 Vlado Puljiz ukazuje na sljedeće sistemske uzroke egzodusa ljudi sa sela: "individualno poljoprivredno gospodarstvo je nedostatna egzistencijalna osnova; poljoprivrednici imaju niži dohodak od drugih kategorija stanovništva, a uz to je taj dohodak nesiguran i neregularan (oscilacije proizvodnje i oscilacije tržišta); poljoprivrednici nemaju neke važne prednosti koje proizilaze iz stalnog radnog odnosa (stalan novčani dohodak, zdravstveno i mirovinsko osiguranje, mogućnost uzimanja kredita, dobijanje stana, dječji dodatak isl.); oni znatno manje koriste institucije opće društvene namjene (škole, komunalne objekte itd.); oni imaju nepovoljniji politički status itd.«(Puljiz, 1973.:101). 
Nakon što se uvidjelo da se, zbog neminovnih poslovnih "mobilizacija« i velikih poreskih nameta, rapidno smanjuje broj stanovnika u ruralnom području, socijalistički poredak je nastojao decentalizovati industrijsku proizvodnju. Istorijski gledano ekonomski razvoj Crne Gore je išao putem snažne koncentracije sredstava i ljudi na malom prostoru, unutar gradsko-industrijskih giganata (Titograda i Nikšića). Na drugom polju, kao posledica toge, i faktorima koje smo ranije naveli, dolazilo do osiromašenja seoskih prostora, prije svega u ljudstvu, a zatim i u svim oblicima ekonomskog i socijalnog života. Crna Gora je za kratko vrijeme ostvarila velike promjene u privrednoj strukturi, promjene u profesionalnoj strukturi stanovništva, te promjene u njegovom teritorijalnom i socio-ekonomskom razmještaju. Neravnoteže stvorene na ovaj način, neophodno je bilo riješiti radi daljeg i sinhronizovanog razvoja cjelokupne teritorije.

S obzirom na razlike u bogatstvima koje stvara industrija, našlo se rješenje u decentralizaciji manjih industrijskih pogona i u njihovom infiltriranju u mehanizme privrednog života osiromašenih crnogorskih varošica. Relativno brzo se formirao manji broj industrijsko-urbanih centara, gdje su koncentrisane privredno značajne grane. Tako je došlo do drugog prostorno disperzivnog pravca investiranja, usmjerenog na izgradnju industrijskih postrojenja u manjim administrativnim centrima Crne Gore.

Kasnije su nastali problemi u socijalističkom, klasno-kolektivnom iracionalnom modelu upravljanja, oko društvene opravdanosti disperzivnog načina investiranja u mala industrijska postrojenja u manjim gradovima, gdje su se pokazivala nedovoljno rentabilnim. Nije se na vrijeme postavilo pitanje da li je recept disperzivnog investiranja najbolji za razvoj brdsko-planinskih sela u nerazvijenim dijelovima Crne Gore (Plužina, Šavnika ili Mojkovca) i da li će on samo promijeniti smjer migracionih kretanja od velikih urbanih centara centralnog regiona, ka malim varošicama posebno sjevernog dijela zemlje, koje u tom periodu bilježe značajan porast broja stanovnika (Bakić i Mijanović, 2006.:33-42).

Ovim korakom se nastojao prevazići decenijski neracionalan odnos prema selu i poljoprivredi, a on je u stvarnosti doveo do potpune deagrarizacija ${ }^{3}$ crnogorskog sela. Takva politika se manifestovala dubokom demografskom krizom u seljačkom društvu, kada je za dvije decenije (od 1961. do 1981.) intezitet urušavanja "poljoprivrednog korpusa bio najdinamičniji i iznosio je čak 34\%. Toliki pad poljoprivrednog stanovništva, za nekoliko decenija, nije zabilježila nijedna bivša jugoslovenska republika.

3 Proces deagrarizacije (kao jedan od ključnih elemenata/posljedica migracije) označava odla-
zak sa zemlje i napuštanje poljoprivrede od strane pojedinih članova porodičnih gazdinstava
ili pak u nekim slučajevima i cjelokupnih porodica koje su kao cjelina napustile bavljenje
poljoprivredom. Sama riječ »deagrarizacija» nastala je kombinacijom latinske riječi ager (polje,
zemlja) i prefiksa de (odvajanje od nečeg). Dakle, doslovno shvaćeno, deagrarizacija znači
odvajanje od zemlje. No nju ne treba, kao što mnogi čine, poistovjećivati sa napuštanjem
sela, odnosno deruralizacijom, budući da se nepoljoprivredno i seosko stanovništvo razlikuju. 
Period socijalističke vladavine (1945.-1991.) završio je u Crnoj Gori smanjenjem udjela poljoprivrednog u ukupnom stanovništvu za više od 8 puta, sa $76 \%$ na 10\% (Bakić i Mijanović, 2006.:95-99). Ubrzano demografsko pražnjenje, a zatim i proizvodno gašenje seoskih zajednica, najznačajnim svojim dijelom je rezultat nepostojanja dugoročne politike razvoja poljoprivrede i sela. Dugogodišnje forsiranje industrije i gradskih naselja, a sistemsko neracionalno djelovanje ili zapostavljanje poljoprivrede i sela, dovelo je do značajnih strukturnih promjena koje nijesu u funkciji njihovog razvoja. »Cjelokupni društveni razvoj u Jugoslaviji, dostignuta razina industrijalizacije i urbanizacije, nisu doveli do formiranja ruralno-urbanog kontinuuma, koji bi zahvatio većinu seoskih naselja i seoskog stanovništva. (...) osjećaj prepuštenosti sebi, osjećaj besperspektivnosti duboko je obuzeo stanovnike sela, koji znaju da vlastitim snagama ne mogu osigurati ulaženje u industrijsku civilizaciju« (Šuvar, 1988.:262).

Poslije pada socijalističkog poretka očekivala se korjenita i brza promjena cjelokupnog društvenog života i seljaštva u njemu. Međutim, u hijerarhiji društvenih aktera seljaštvo kao »konglomeratski sloj« svakako spada u one koji su manje sposobni za sveopšte društvene promjene. Pošto tranzicija (transformacija) jednog sistema upravljanja - socijalizma, u osnovi znači uspostavljanje jednog novog, društveno humanijeg poretka (kako su se mnogi nadali) preko afirmacije privatnog vlasništva, seljačko gazdinstvo je u odnosu na sve ostale društvene aktere imalo povoljniju startnu poziciju. "Dakako, ukoliko je ono sa svojim porodičnim gazdinstvom sposobno funkcionirati u novoj, nesocijalističkoj stvarnosti. Izgleda kao da je seljaštvo sa propašću realsocijalističkog poretka došlo na svoje. Je li tome tako? Jesu li seljačka ekonomija i ukupan način života seljaštva kompatibilni suvremenom neoliberalizmu? Ili možda između ova dva sistema, seljačke i liberalne ekonomije, postoje značajna nesaglasja? Jesu li za seljaštvo problemi koji proizilaze iz realsocijalističke konstrukcije prestali, a drugi tek nastali?« (Hodžić, 2000.:80). Sva pitanja koja je postavio Hodžić relevantna su i za crnogorsko selo koje je jednako podijelilo i podnijelo sve patnje i krizu sa urbanim društvom Crne Gore. "Tranziciona kriza se manifestovala kroz povećanu stopu nezaposlenosti, nedovoljnu ekonomsku aktivnost, kriminalizaciju privrede, produženu pauperizaciju, a rat u okruženju samo je dolio ulje na vatru crnogorske transformacijske drame« (Vukićević, 1998.:110).

U ovako nepovoljnom ambijentu šanse za revitalizaciju crnogorskog sela svedene su na minimum. Djelimično izvršena svojinska transforacija velikih poljoprivrednih preduzeća, i dalje neriješeno pitanje prilagođavanja sitnoseljačkog sektora tržišnoj privredi, nedostatak kapitala za opremanje modernom mehanizacijom i opremom, neizgrađena tržišna infrastruktura u službi poljoprivrednih porodičnih gazdinstava, činili su glavne karakteristike kojima se ovaj period agrarnih odnosa Crne Gore može "pohvaliti«.

Trend pada broja stanovnika koji žive na selu i bave se poljoprivredom se i dalje nastavlja, i ono što se ističe kao glavni pokazatelj neadekvatnog državnog odnosa prema selu u Crnoj Gori danas, je smanjenje učešća broja poljoprivrednika samo u posljednjih osam godina za 3 postotna poena udjela u ukupnom stanovništvu, što svakako nije mali broj ni za veća, razvijenija društva, a kamoli za crnogorsko društvo (Monstat, 83/2012.:10-14). Navedeni pokazatelji jasno demonstriraju dece- 
nijski neadekvatan sistemski odnos prema selu i kao posljedicu tome, depopulaciju ruralnog područja s tendencijama radikalizacije do potpunog iščezavanja njegovog stanovništva.

Grafikon 2.

Udjel poljoprivrednog u ukupnom stanovništvu Crne Gore od 1931. do 2011.

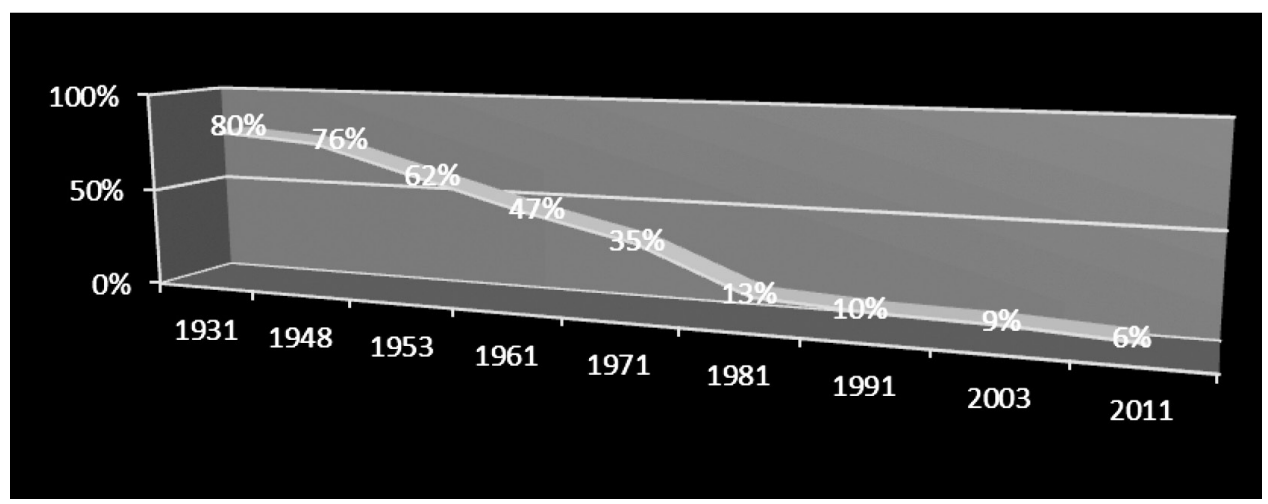

Izvor: Bulajić, 1959.:267; Bakić i Mijanović, 2006.:95-99; Monstat, 83/2012.:10-14

\section{Senilizacija porodičnih gazdinstava u Crnoj Gori}

Pod uticajem društveno-sistemskih faktora, odliva velikog broja stanovništva sa gazdinstava, deagrarizacije sela i njegove opšte depopulacije, u ruralnim sredinama Crne Gore, teče paralelno i proces senilizacije sela i porodičnih poljoprivrednih gazdinstava. Navedne pojave spadaju u regresivne i degradirajuće (devastacione) društvene procese, kojima su posebno zahvaćeni nerazvijeni brdsko-planinski seoski regioni u Crnoj Gori. Što je neko selo (ili seoski region) izolovaniji i manje razvijen, iz njega više odlaze mladi ljudi, a na gazdinstvima ostaju samo stariji - bez djece i bez perspektive.

Proces senilizacije je u stvari proizvod selektivnih učinaka migracije na starosnu strukturu i sa sobom donosi višestruke i značajne ekonomske, društvene i kulturne posljedice. On dovodi do toga da u selima slabi socijalna i biološka reprodukcija stanovništva (brzo se smanjuje ili je već i nema), privredna aktivnost se svodi na minimum, dolazi do disproporcije polnih grupa, mijenja se kompletna starosna struktura sela, a posebno poljoprivredno sposobnog stanovništva, smanjuje se rapidno njegov broj, zamire društveni, ekonomski i kulturni život. Svetozar Livada sjajno ukazuje da su »socijalni kontakti u mjestu njihova života svedeni na minimum (ukopi, rjeđe svadbe i pokoja posjeta). Djeca k njima dolaze više da nešto ponesu nego da ih obiđu 'njima se vječno žuri, jer pate od oskudice vremena. (...) Klanjajući se pred očevima, saginjući se za djecu, oronuli, bačeni smo na koljena od društva koje smo stvarali' - kažu seljaci za sebe i za svoje« (Livada, 1972.:10). U takvim okolnostima ostarjeli poljoprivrednici često se nalaze u bezizlaznim socijalnim prilikama i moraju posegnuti za onim što im jedino preostaje, a to je prodaja gazdinstva. 
U Crnoj Gori ovaj problem dugo vremena nije dublje istraživan i ignorisan je sve do posljednjih nekoliko decenija, kada je pokazao svoju ekstremnu društvenu traumatičnost. Sociolozi su u početku nazirali probleme starenja seoske populacije, da bi kasnije uvidjeli njegov dramatičan značaj, te da bi ga danas smatrali društveno-patološkom pojavom. Stanovništvo crnogorskih sela se 1971. godine teško moglo svrstati u neki čisti tip starosne strukture. Učešće starih lica je i tada bilo znatno veće, posebno na ruralnom području, te su razlike između seoskog i gradskog stanovništva bile primijetne. Međutim, gradsko stanovništvo Crne Gore ne samo da je bilo mlađe od seoskog stanovništva, već je ono bilo najmlađe u bivšoj Jugoslaviji.

Prema rezultatima posljednjeg popisa poljoprivrede na crnogorskim gazdinstvima danas živi 98.949 ljudi, koji ujedno i predstavljaju radnu snagu gazdinstava. Starosnu strukturu poljoprivrednih gazdinstava u Crnoj Gori karakteriše visok udio starijih radno angažovanih lica na gazdinstvu i mali broj mlađih članova (grafikon 3). Od ukupnog broja radno sposobnih žitelja njih 23.204 su osobe starije od 65 godina. Proces senilizacije sela je duboko zahvatio sve pore crnogorskih ruralnih zajednica, jer je danas skoro 44\% ukupnog broja radno angažovanih na gazdinstvu iznad 55 godina starosti. Najmanje je onih kojih bi u progresivnim gazdinstvima trebalo da je najviše, svega $7 \%$ radne snage na crnogorskim gazdinstvima je mlađe od 24 godine (Monstat, 68/2010.:17).

Grafikon 3.

Dobna struktura radne snage na porodičnim gazdinstvima u Crnoj Gori 2011. godine

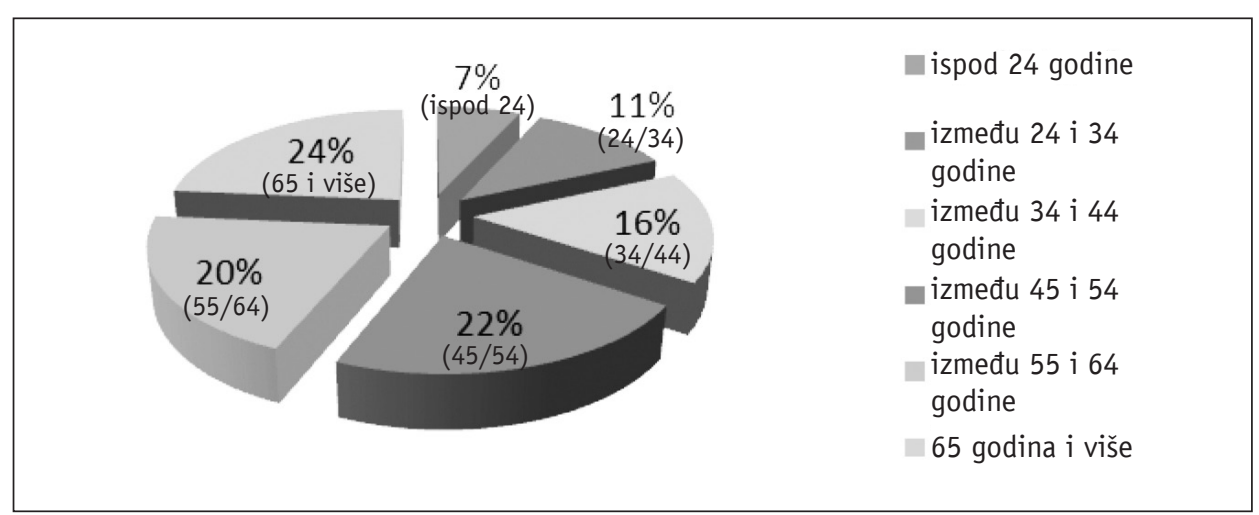

Izvor: Monstat, 68/2010.:17

Drugo, najviše porodičnih poljoprivrednih gazdinstava u Crnoj Gori broji između jednog i četiri člana. Od ukupnog broja gazdinstava (48.824) ubedljivo je najviše onih gazdinstava koja broje od 1 do 2 člana, čak 37.518 ili 76,8\%; 3 do 4 člana ima 9.686 (19,84\%) gazdinstava; 5 do 7 članova broje 1.424 (2,93\%) gazdinstva dok je ubedljivo najmanje onih gazdinstava s više od 7 članova koja su nekada činila okosnicu ruralnog područja, njih ima svega 196 ili 0,43\%. Uzimajući u obzir starosnu strukturu i veličinu porodice na gazdinstvu, možemo slobodno tvrditi da je na crnogorskom selu najviše ostalo starih bračnih parova ili samaca, te da oni danas čine osnovu na kojoj se gradi siguran nestanak i crnogorskih porodičnih gazdinstava i sela u cjelini. 
Grafikon 4.

Struktura porodičnih poljoprivrednih gazdinstava Crne Gore po broju članova, 2011. godine

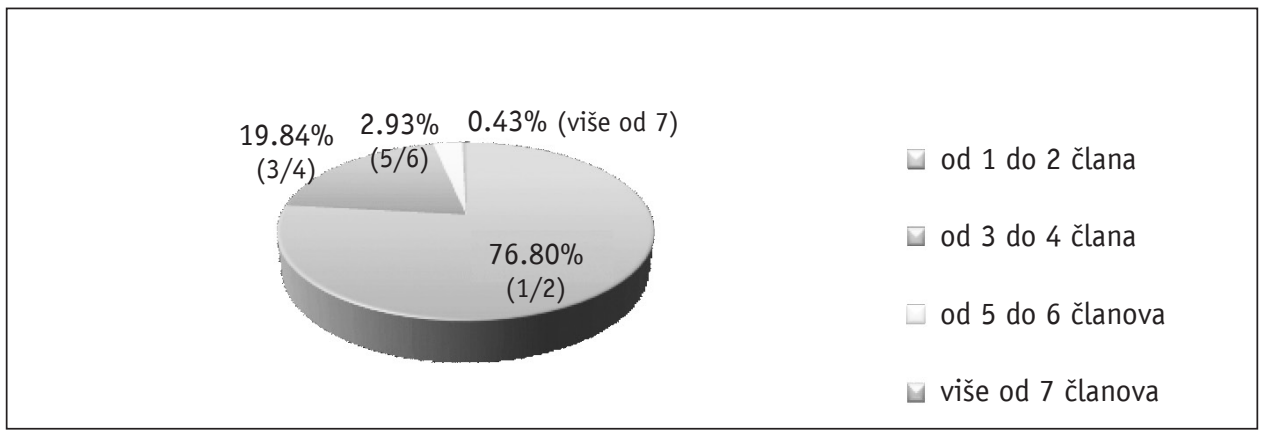

Izvor: Monstat, 68/2010.:17

Demografska kretanja su ostavila značajan trag na život i funkcionisanje porodičnog gazdinstva, a posljedice koje su iz navedenih procesa proistekle, čine danas osnovu koja bitno determiniše život ruralnog područja zemlje.

Za kraj dajemo veoma interesantnu analizu života starih seljaka u Crnoj Gori, koji nisu ostali na svome ognjištu, autora Zorana Gudovića. On ukazuje na činjenicu da u Crnoj Gori nijesu samo mladi napuštali sela, već su to činili preostali starci koji su zbrinjavani kod svoje djece u varoši. "Kako njihovi potomci često žive na periferiji gradova u prigradskim naseljima, kulturni šok koji bi podrazumjevao prelazak iz zaostalog sela u novu gradsku sredinu bio je amortizovan geografskim i prirodnim ambijentom za koji se ne može reći da je tipično gradski. Na širem području prilaza Podgorici stiješnjeni između brda i glavnog magistralnog puta sve do osamdesetih godina mogli su se vidjeti stariji muškarci odjeveni u narodnu nošnju kako sjede ispred svojih kuća skriveni u debelom hladu loze i drugog mediteranskog rastinja. Ova domaćinstva su uz neizbježne kulturne promjene kojima su bila zahvaćena, čuvala običaje, njegovala čvrste susjedske veze, gajila stoku i živinu i po svemu sudeći u većoj mjeri doprinosili ruralizaciji grada, nego vlastitoj urbanizaciji i nastojanju da se kao seljaci promijene» (Gudović, 2008.:88).

\section{Zaključak}

Ubrzano demografsko pražnjenje, a zatim i proizvodno gašenje seoskih zajednica Crne Gore, prvenstveno su rezultat nepostojanja dugoročne politike razvoja poljoprivrede i sela. Socijalistički sistem je prije svega, pokretanjem ambicioznih projekta transformacije društva, temeljno uzdrmao dotadašnju agrarnu strukturu i tradicionalni način života seljaka. Industrijalizacija, nacionalizacija, kolonizacija, kolektivizacija, plansko usmjeravanje proizvodnje, osnovne su mjere kojima se nastojalo preovladati zatečeno poslijeratno stanje. Primjenjivani su neadekvatni i za demokratska društva grubi oblici pritisaka na seljaštvo. Individualna poljoprivredna proizvodnja prestaje biti privredna grana od posebnog društvenog značaja, što je snažno uticalo na sveukupni integritet sela, seoskog društva i života u samom gazdinstvu. Gazdinstvo 
stagnira i postaje sve beznačajniji dio društvene strukture, lišen gotovo svih uticaja u društvenom lancu djelovanja.

Posmatrano sa sociološkog aspekta, egzodus ljudi sa sela i deagrarizacija su složeni društveni procesi u čijoj osnovi leže pojam kretanja, promjena, razvoja grada i devastacija sela kao trajne činjenice. Osnovne karakteristike koje ga u Crnoj Gori krase su brzina kojom se dešava i masovnost. Međutim, nema ni jedne nagle društvene promjene, koja sa sobom nije povukla i niz drugih društvenih promjena, koje će naravno pogoditi i samu osnovu društva, proizvodnju, potrošnju, kao i cjelokupan život stanovnika. Kada se na tom nivou razmišlja o rehabilitaciji i obnovi devastiranog ruralnog aglomerata Crne Gore, važnije je i za društvo daleko značajnije, kako i na koji način sačuvati ona naselja koja su zbog procesa deruralizacije na ivici vlastitog nestanka. Jer jednom odumrla sela, nemoguće je "oživjeti« kao što se pokušava, a onda je način njihove revitalizacije mnogo bolje teorijski konceptualizovati, društveno organizovati i sprovoditi kao moderan razvojni projekt kojim će se planski, ali i spontano i stihijski mijenjati dosadašnji neracionalan način seoskog života: prirodna i društvena reprodukcija seoskog stanovništva, povratak mladih ljudi ruralnoj sredini, porodični odnosi, organizacija i način poljoprivredne proizvodnje i drugih privrednih djelatnosi u selu, korišćenje prostora, organizacije kulturnog života u ruralnoj zajednici i komunikacija sa širim društvom i civilizacijskim tvorevinama.

* Tekst je lektorirala profesorica Majda Mirković (Filozofski fakultet u Nikšiću).

\section{Literatura}

1. Andrijašević, Ž. i Rastoder, Š. (2006). Istorija Crne Gore. Podgorica: Centar za iseljenike Crne Gore.

2. Bakić, R. i Mijanović, D. (2006). Demografska kretanja u Crnoj Gori tokom druge polovine XX vijeka. Nikšić: Geografski institut Filozofskog fakulteta.

3. Bulajić, Ž. (1959). Agrarni odnosi u Crnoj Gori 1978-1912. Titograd: Istorijski Institut Crne Gore.

4. Gudac, V. (1994). Politika Komunističke partije Jugoslavije 1945-1953. godine, kao faktor blokiranja modernizacijskih procesa na selu, u: Perović, L. (Ur.). Srbija u modernizacijskim procesima XX vijeka. Beograd: Institut za noviju istoriju Srbije.

5. Gudović, Z. (2008). Selo i seljaštvo - prilog sociologiji sela. Beograd: Standard.

6. Hobsbaum, E. (2002). Doba ekstrema. Beograd: Dereta.

7. Hodžić, A. (2000). Socijalna struktura i mobilnost seoskog stanovništva. Sociologija sela, 147/148: 79-107.

8. Horvat, B. (1976). Jugoslovenska agrarna teorija i politika u poslijeratnom razdoblju. Pregled, 7-8: 785.

9. Livada, S. (1972). Naše društvo i stari seljaci. Sociologija sela, 37-38: 5-14.

10. Livada, S. (2004). Sudbina crnogorskih ruralnih naselja nastalih za bistorijski trenutak. Podgorica: CANU.

11. Mitrović, M. (1997). Sociologija sela. Beograd: Službeni glasnik. 
12. Puljiz, V. (1977). Eksodus poljoprivrednika. Zagreb: Centar za sociologiju sela, grada i prostora Instituta za društvena istraživanja Sveučilišta u Zagrebu.

13. Seferagić, D. (Ur.). (2002). Selo: izbor ili usud. Zagreb: Institut za društvena istraživanja u Zagrebu.

14. Šuvar S. (1988). Sociologija sela II - Socijalizacija poljoprivrede i urbanizacija sela. Zagreb: Školska knjiga.

15. Veselinov, D. (1987). Sumrak seljaštva. Beograd: Ekonomika.

16. Vukićević, S. (1998). Simuliranje promjene (transformacija socijalizma). Cetinje: Obod.

17. Zavod za statistiku Crne Gore - Monstat (2010). Prvi rezultati popisa poljoprivrede 2010. godine za porodična poljoprivredna gazdinstva. Podgorica: Saopštenje broj 68 .

18. Zavod za statistiku Crne Gore - Monstat (2012). Popis stanovništva, domaćinstava i stanova u Crnoj Gori 2011. godine. Podgorica: Saopštenje broj 83.

19. Zavod za statistiku Crne Gore - Monstat (2011). Prirodno kretanje stanouništva i unutrašnji migracioni tokovi u 2010. godini. Podgorica: Saopštenje broj 98.

20. Zavod za statistiku Crne Gore - Monstat (2012). Prirodno kretanje stanouništva u Crnoj Gori, 2011. godina. Podgorica: Saopštenje broj 102. 
Prethodno priopćenje

Rade Šarović

Faculty of Philosophy in Niksic, Department of Sociology, University of Montenegro, Montenegro

e-mail: sarovicrade@gmail.com

Migration of Farmers in Montenegro (1948.-2011.)

\begin{abstract}
For rural areas of Montenegro recent decades are characterized by distinct discontinuity in the development. In Montenegro, as well as in economically more developed parts of the world, industrialization caused the process of deagrarization and deruralization and manifested in the reduction of the agricultural population in total population, and reduction of the number of residents who remain to live in villages. The specificity of these changes in Montenegro was reflected in the fact that the process went very quickly, much faster than in neighboring countries and in more developed parts of the world. The share of agricultural population in total population, reduced 12 times for six decades - from about $80 \%$ immediately after the Second World War, to below 10\%, according to the latest estimates. In a short period of time (even unnaturally short for this type of social processes) an enormous number of people changed occupation, place and style of living. This paper presents a brief summary of the Montenegrin rural dramas in recent decades, which end is not in sight.
\end{abstract}

Key words: village, population trends, migration, deagrarization, deruralization, Montenegro, aging population. 